\title{
Kunskap omfattar fakta, förståelse, förmågor och omdöme. Högskolans uppgift är att utveckla all fyra, men främst omdömet
}

Här börjar jag med att reda ut vad vi kan mena när vi talar om kunskap. Vilken slags kunskap borde prioriteras i högskolan? Kan högskolan stödja en bildningsprocess där människan skapar sig själv genom att öva upp sitt omdöme?

\section{Kunskap som kameleont}

Vi borde rimligen vara överens om vad vi pratar om när vi pratar om kunskap. Eller åtminstone vara medvetna om att vi inte är överens. Kunskap är högskolans livsluft, dess råmaterial, dess process och dess produkt, men ordet självt är vi ganska slarviga med. Jag tänker inte här försöka göra en historisk exposé över kunskapsbegreppets idéhistoria eller redovisa forskningsläget. Jag vill bara försöka förstå och sedan belysa vad jag menar med ett antal ord och begrepp som är viktiga när jag skriver om vad en högskola är och skulle kunna vara.

Kunskap, både som ord och som begrepp, är en bedräglig kameleont. Ordet antar det omgivande argumentets färger och kan plötsligt uppträda i en helt ny skepnad utan att vi märker det. Eftersom det används omväxlande i ett antal smalare eller bredare, ibland helt motsägelsefulla, betydelser, bildar det också grunden i bedrägliga argument. För något decennium sedan användes,

How to cite this book chapter:

Casson, A 2015 Högskolans ansvar: Principer för utveckling av den högre utbildningen.

London: Ubiquity Press. DOI: http://dx.doi.org/10.5334/bap.a License: CC-BY 3.0 
till exempel, "kunskapsskolan" som slagträ i debatten; den uppfattades som motpol till "flumskolan" i den mediala verkligheten och tänktes väl därmed ha mycket av faktainlärning och "kunskapskontroller" på schemat. De som var emot kunskapsskolan var emot kunskap.

"Kunskapssamhället" är ett annat exempel på en flitigt använd sammansättning med luddigt innehåll och flytande konturer. Kunskapssamhälle används omväxlande med informationssamhälle och även om skillnaden mellan förleden egentligen är helt avgörande, menar man i dagligt tal ungefär samma sak. Det är, kort sagt, att samhällets framgång, åtminstone i vad som kallas de utvecklade länderna, inte längre främst bygger på produktion av varor utan på att människor utför tjänster åt varandra och att dessa tjänster - i vården, $\mathrm{i}$ skolan, i industrin också - i hög grad bygger på specialiserad kunskap. Jord, arbete och kapital räckte för industrisamhällets produktion, tycks man säga, men nu behövs också kunskap. Det är inte längre på produktionen av mat, kläder eller bilar som ett samhälles framgång beror. I kunskapssamhället blir det land framgångsrikt som kan producera bäst och mest kunskap.

Och nu dyker den första frågan upp: kan man överhuvudtaget producera, eller, för den delen, konsumera kunskap? Om kunskap är information så kan man det, förstås. Man kan genom systematisk undersökning ta reda på hur, till exempel, en viss sjukdom sprids och sedan skriva ned sina insikter och publicera dem. Författarna äger en viss kunskap som de omvandlar till information i en artikel. Men läsarna måste sedan genom sitt läsande, sitt lärande och sin förståelse åter omvandla informationen till kunskap.

Det vore lysande om vi kunde reservera orden information och kunskap för just dessa betydelser: information utgör påståenden om sakförhållanden medan kunskap finns hos en eller flera människor och innebär någon form av förståelse. Bara en sådan bruksdefinition skulle göra det mycket enklare att tala om högskolans uppgifter. Men med språk är det så att vi inte ensidigt får slå fast ords betydelse, åtminstone inte utanför enskilda språkreservat. Bara i en bok där författaren talar om för läsaren att "när jag skriver x så menar jag y" eller inom en viss vetenskaplig disciplin där forskarna har en tyst överenskommelse, eller åtminstone ett livligt meningsutbyte, om innebörden i sina centrala ordverktyg får man själv definiera sina begrepp. Vi får helt enkelt acceptera att kunskap är ett begrepp som används luddigt och bedrägligt och se till att vi, varje gång vi använder det, talar om vad vi menar. Jag återkommer strax till ett förslag på hur vi skulle kunna göra detta, men först vill jag bara kort beröra ett begreppspar som också ofta ställer till besvär i diskussioner om kunskap, nämligen teori och praktik.

\section{Ingen teori utan praktik, ingen praktik utan teori}

I utbildningsdebatten, och inte så sällan bland högskolans lärare och studenter, talar man om teori och praktik som om de vore olika världar, väl åtskilda och 
tämligen oproblematiska att skilja åt. Teorin är det man ägnar sig åt i skolan och ännu mera i högskolan. Praktik är det som drabbar en i det verkliga livet. "Ute i verkligheten", säger man, som om högskolan vore Platons grotta där alla figurer och händelser är blott skuggor av en verklighet som pågår utanför.

Och visst: folkmedicinen kan bota sjukdomar utan att förstå varför det lyckas och forskare i humanbiologi kan ha en förståelse för varför sjukdomar uppstår utan att kunna bota dem. En snickare kan bygga ett hus utan att kunna redogöra för hållfasthetsteori, som en ingenjör i sin tur kan göra kalkyler utifrån utan att nödvändigtvis kunna bygga hus. Så långt kan teori och praktik skiljas åt, men snickaren begriper trots det hållfasthetsteorins konsekvenser utan att nödvändigtvis kunna artikulera teorin. Och hennes färdighet som snickare kommer att förbättras genom att hon begriper och kan artikulera teorin. Hennes kunskap fördjupas. Självklart finns det många fall där teorin inte påtagligt kommer att förbättra ett praktiskt utförande: en komplex teoretisk beskrivning av armens hållning och hammarens bana kommer inte att påtagligt förbättra min förmåga att slå i en spik. ${ }^{5}$ Genom att lära sig snickra, alltså genom tusentals handfasta experiment av trial and error-typ, kan ingenjören fördjupa och nyansera sin teoretiska kunskap men framförallt få bättre insikt och omdöme i sitt arbete. En teori är ett artikulerat tänkande om en praktik. En praktik är en mängd iscensatta teorier, oavsett om de är kända eller artikulerade av utföraren eller inte, eller ens av någon annan.

Teori och praktik utgör alltså varandras nödvändiga komplement. De kan aldrig stå i motsats till varandra. De kan ju inte heller motverka varandra. Det finns icke desto mindre en utbredd uppfattning att den som läst mycket teori blir en sämre praktiker och att duktiga hantverkare saknar teoretisk förståelse. ${ }^{6}$ Och när man väl delat upp människor i teoretiker och praktiker, tilldelas teoretikern av hävd ett högre värde, åtminstone i samhällets makt- och lönestrukturer. ${ }^{7}$ Bland dem som utför ett arbete i den så kallade verkligheten utanför högskolan, är synen på teori ofta mycket skeptisk, lustigt nog också bland dem

${ }^{5}$ Exemplet med hammaren är klassisk och utnyttjas tillsammans med bl. a. cykelåkandet av den ungerska vetenskapsfilosofen Michael Polanyi i Personal Knowledge från 1958 där han för första gången introducerar begreppet tacit knowledge, tyst kunskap - för förmågan att slå i spik, att cykla, att kunna tala ett språk, där den ännu oartikulerade teorin inte är nödvändig för utförandet, där förmågan inte kan läras genom att begripa teorin.

${ }^{6}$ Själva Immanuel Kant ger ett perspektiv på detta i en uppsats med titeln: "On the Common Saying: 'This May be True in Theory, But it Does Not Apply in Practice"'. Teorin ger oss generella regler, säger Kant, men inte omdömet att kunna tillämpa dem: "[T]he general rule must be supplemented by an act of judgement whereby the practitioner distinguishes instances where the rule applies from those where it does not... There are doctors and lawyers who did well during their schooling but who do not know how to act when asked to give advice.... No-one can pretend to be practically versed in a branch of knowledge and yet treat theory with scorn, without exposing the fact that he is an ignoramus in his subject." (Citaten återges tillsammans med ett resonemang om Kant i en uppsats med titeln 'Theory and Practice' av James Rachels http://www.jamesrachels.org/theory.pdf hämtad 2013-02-22)

7 Redan Aristoteles gav det teoretiska livet, bios theoretikos, det högre värdet, förbehållet ett fåtal, till skillnad från bios apolautikos, hantverket som alla kunde ägna sig åt. (Gustavsson 2009, s 74ff) 
som själva har en längre teoretisk utbildning bakom sig. Diskussionen om teori och praktik är viktig i högskolan och förs intensivt av dem som arbetar inom utbildningar med mycket verksamhetsförlagda inslag, inte minst vård- och lärarutbildningar. Att man försöker låta begreppet verksamhetsförlagd utbildning, VFU, ersätta det gamla "praktik" visar en medvetenhet om problemet.

Med dessa förbehåll om teori och praktik, kan jag nu pröva återge hur jag förstått vad det är som händer i den teoretiska undervisningen, det som uppfattas som högskolans kärna.

\section{Information, förståelse, omdöme}

Ganska ofta inom högskolans värld säger vi att vi ägnar oss åt att förmedla kunskap. Som om läraren vore en mellanhand som ska presentera ett kunskapsstoff, oftast producerat av någon annan, någon annanstans, på ett aptitligt sätt och i lämpliga portioner för att konsumenten - studenten - ska inmundiga det. Och börjar man skrapa på de mest spridda föreställningarna om hur undervisning och utbildning går till, så är det just denna bild som framträder: läraren har att öppna skallbenet på studenten, en pedagogisk trepanation, och genom sin väldesignade tratt hälla i kunskapen. Beroende på hur stor kapacitet studentens hjärna har, kommer hon att lyckas olika väl i att ta emot och förvara kunskapen. Hur bra det går för henne kan kontrolleras i prov och tentamina där hon får återge kunskapen. Korrekt återgivning ger poäng. När man samlat tillräckligt med poäng kan man få en examen och förhoppningsvis ett jobb där man under ett helt yrkesliv kan använda sig av de kunskaper som man samlat på sig. Lite tillspetsat kanske, men det finns många, både studenter och lärare och allmänhet och politiker, som i stort sett tänker så här. Och det är nog den och liknande föreställningar om kunskap och kunskapsförmedling som bildar grunden för de kvantitativa effektivitetsmätningar och incitament - genomströmning, prestationsersättning och liknande - som man använder för att försöka göra högskolan bättre. Kunskap kan dock aldrig förmedlas, eftersom kunskap förutsätter förståelse och förståelse ett aktivt arbete från mottagarens sida. Information kan förmedlas.

Vi bör alltså skilja mellan information eller fakta, å ena sidan, och förståelse eller insikt å andra sidan. Förståelse är någonting som människor skapar hos sig själva genom en aktiv ansträngning: de försöker förstå. Bäst verkar de göra det i samtal med andra. Samtalen kan förstås utformas på många olika sätt, som seminarier, runt fikabord, i brevväxling eller i kommentarer till en inlämnad uppgift eller som kritik på en artikel man läst. En bok kan tillhandahålla information, men innehållet blir kunskap först när boken är läst och förstådd av en människa. Och varje människa kommer att läsa boken på sitt sätt, kommer att skapa sin egen förståelse som bygger på hela den ryggsäck av tidigare erfarenheter och föreställningar hon bär med sig. Den förståelse som läsningen bidrar till blir oftast djupare om den i ett samtal också delas med andra som läst 
samma bok. En föreläsning har ungefär samma funktion som en bok - det är information som görs tillgänglig. Själva ordet föreläsning kommer av att man helt enkelt läste upp texter, innan böcker var så lättillgängliga som de är nu. Ibland påstår studenter att föreläsare fortfarande ägnar sig åt detta. En skillnad mot boken är dock att föreläsaren med sin fysiska uppenbarelse och alla sina mänskliga egenheter finns i samma rum och har lättare att samspela med sin publik, att läsa av ansikten, att svara på enstaka frågor. Men föreläsningen finns inte kvar när den är slut - såvida inte den kloka studenten eller läraren spelat in den förstås - och kan inte återupplevas, rådfrågas, läsas om, på samma sätt som en bok. Någon slags förståelse blir det oftast ändå, även om graden och arten av förståelsen påverkas starkt av en hop andra ingredienser som förförståelse, motivation, ambition och engagemang. Den påverkas också av sin tid. Vi förstår Strindberg på ett annat sätt idag - inte "bättre", bara mycket annorlunda - än vi skulle ha gjort om vi hade läst honom när han levde för över hundra år sedan.

Jag nämnde nyss insikt, som om den vore likställd med förståelse, och till vardags är den nog det. Men det finns, som jag uppfattar det, en viktig nyansskillnad. Förståelse innebär att jag har satt in den information jag tagit till mig i ett sammanhang, att den hänger ihop med annat jag vet och jag förstår hur. Därutöver kräver insikt en gnutta omdöme. ${ }^{8}$ Och omdöme i sin tur kräver inte bara att man förstår, att man äger kunskapen, utan också att man förstår att rätt kunna bruka den. Rätt är ett viktigt ord här, bruka ett annat. Så snart vi säger rätt, ger vi oss iväg från objektivitetens och oberoendets trygga hamn ut på moralens och etikens stormpiskade hav. Där finns vindar och strömmar som kan föra oss ohjälpligt fel; navigationskonsten består i att utveckla ett omdöme. Det kan ingen göra åt oss utan vi måste göra det själva. Det gör vi i en livslång bildningsprocess, något jag återvänder till strax, men utbildning har en viktig roll att spela i att utveckla omdömet, något som skulle behöva speglas betydligt starkare i våra utbildningar i högskolan.

När vi sedan brukar våra insikter sker det i någon form av handling. Det behöver inte vara en fysisk handling utan kan mycket väl bestå $\mathrm{i}$ att säga något eller skriva något, att delta i ett samtal och därmed sätta igång eller bidra till en kedja av händelser som åstadkommer en förändring. Och om vi kan göra detta på ett ändamålsenligt sätt kan vi hävda att vi besitter en viss (handlings-) förmåga. Just begreppet handlingsförmåga försöker jag bena ut lite längre fram, under Princip 4.

Om jag stannar upp här och ser efter hur långt resonemanget har kommit, uppenbarar sig en kedja som ser ut så här: ${ }^{9}$

${ }^{8}$ Georg Henrik von Wright är väl den bland svenskspråkiga vetenskapsfilosofer som i modern tid tydligast påpekat att vetenskapen inte är "förnuftig", d.v.s. klok, i sig. Säkerställbar kunskap måste kompletteras med omdöme, en bedömning av vad som är det rätta och det goda (v Wright Vetenskapen och förnuftet 1986).

9 Den här serien påminner inte så lite om Aristoteles begrepp i Den nichomachiska etiken: episteme (faktakunskap), techne (praktisk kunskap), phronesis (praktisk klokhet) och slutligen sophia (visdom). Se Liedman 2001, s 323 och Gustafsson 2002, s 13. 
Information/fakta -> förståelse/insikt -> omdöme -> handlingsförmåga

Här kan symbolen -> uttydas “är en förutsättning för", snarare än "leder till”. Det finns ju mycket information vi inte begriper, hur ofta vi än hört den och det finns många insikter som knappast kan sägas förenas med ett gott omdöme. Men även där vi tycker att någon handlar uppenbart fel eller omdömeslöst, har den trots allt handlat utifrån bästa förstånd, som vi säger. När vi vill vara riktig elaka säger vi att någon handlar som han har förstånd till.

Lärande blir då processen från vänster till höger, där människor ensamma, eller allra bäst tillsammans, aktivt tillgodogör sig information och söker förståelse. ${ }^{10}$

Men även om vi skulle vilja reservera ordet kunskap för en enda länk i kedjan, helst förståelselänken kanske, låter det sig inte göras. Vi får låta kunskap bli ett paraply över alltihopa och använda begreppet med måtta och urskiljning. Och i diskussioner om kunskap behöver vi alltid på något sätt tala om vilken eller vilka delar vi menar.

\begin{tabular}{|ccccccc|}
\hline $\mathrm{K}$ & $\mathrm{U}$ & $\mathrm{N}$ & $\mathrm{S}$ & $\mathrm{K}$ & $\mathrm{A}$ & $\mathrm{P}$ \\
Information/fakta & $->$ & förståelse/insikt & -> & omdöme & -> handlingsförmåga \\
\hline
\end{tabular}

Att använda kunskap i denna vida bemärkelse har sina fördelar. Vi kan till exempel säga att all kunskap är provisorisk. Det vi håller för sant är sant så länge vi inte hittat en bättre sanning. En sanning är också bara intressant så länge den $g a ̊ r$ att överbevisa, att falsifiera. ${ }^{11}$ Men inte nog med att kunskapen är provisorisk, den är också högst beroende av sin omgivning. Den finns hos människor och människan är alltid placerad i tid och rum, innesluten i ofta omedvetna kollektiva föreställningar om verklighet och sanning.

Filosofen Mats Rosengren inleder sin essä om kunskap, Doxologi med en fråga "Vad betyder det att all kunskap som vi människor har - alltifrån teoretiska insikter till praktiska färdigheter - är just vår kunskap?"12 Han menar att all kunskap är doxisk, d.v.s. helt beroende av vad vi tror om världen och oss själva. Vi behöver vända oss bort från tanken att det finns en säker kunskap, menar han, eftersom det alltid finns en tolkning bakom varje så kallat faktum.

\footnotetext{
${ }_{10}$ Den brittiska vetenskapshistorikern och litteraturvetaren Stefan Collini belyser förhållandet i ett par pedagogiskt avslöjande formler: Skills + information $=$ knowledge menar Collini är en gängse föreställning, medan det egentligen förhållandet är experience + judgement $=$ understanding (Collini, 2012, s 77).

11 "Falsifierbarhet” är vetenskapsfilosofen Karl Poppers begrepp. Han presenterar den i The Logic of Scientific Discovery (1959) så här enkelt "it must be possible for an empirical scientific system to be refuted by experience" (s 41 förf:s kurs) ...

12 Rosengren 2008, s 10 (förf:s kurs)
} 
Det innebär att det inte bara finns en kunskap eller sanning, utan många, och att all kunskap är betingad av de individuella, sociala, historiska och diskursiva förhållanden inom vilken den producerats. ${ }^{13}$

Jag tänker alltså vara lite försiktig med hur jag använder kunskapsbegreppet i en diskussion om högskolans mål och medel. Men i den här korta diskussionen skymtar faktiskt redan några av de viktigaste bland dessa. Bland målen finns att formulera och ompröva fakta, att uppnå förståelse och att främja omdömet och därmed förmågor. Bland medlen finns lärandet och bildningsprocessen. Bland nödvändiga insikter som behöver odlas finns den om sanningens provisoriska väsen och dess beroende av människan i hennes sammanhang.

\section{Bildning är att skapa sig själv}

I denna min första princip hävdar jag att det är just omdömet som borde vara i främsta fokus för den högre utbildningen. Omdöme är att rätt kunna bruka den kunskap man äger, skrev jag, och omdömet kan man utveckla i en bildningsprocess. Bildning framhävs mycket riktigt ofta som ett ädelt mål för den högre utbildningen. Liksom så många andra honnörsord i den högre utbildningen växlar dock inte bara dess popularitet med tiden, utan också de betydelser man lägger in i begreppet.

Så, om bildningen utvecklar omdömet, vad är då bildning? Ja, det är åtminstone inte allmänbildning, frestas man att säga. Och det är möjligt att man borde bortse från dem som sätter likhetstecken mellan bildning och den slags allmänbildning eller kulturellt allmängods som bidrar till framgång i frågespel. Samtidigt kan man inte bortse ifrån att i stort sett samma allmängods, använt vid rätt tillfälle, uttryckt på rätt sätt, leder till framgång inte bara i frågespel utan också i det maktspel som kallas kultiverat umgänge. Det ger åtminstone en fernissa åt vad som i den humanistiska och samhällsvetenskapliga forskningen de senaste decennierna kallats kulturellt kapital. ${ }^{14}$ Bildning blir en form av klassmarkör som hänger ihop med förfinad smak och högkulturella intressen - baletten, operan och kammarmusiken, till exempel. Och det är svårt att skilja ordet från den innebörden, åtminstone i den allmänna debatten och i dagligt tal utanför specialiserade akademikerkretsar.

De som trots allt vill rädda begreppet bildning från att sväva ut i allehanda bibetydelser som dessa, hänvisar gärna till dess ursprung i den tyska filosofin hos Herder och Hegel och påminner sedan om hur Humboldt använde sig av

${ }^{13}$ Rosengrens resonemang bygger på Protagoras sats, den så kallade homo mensura-satsen, där människan är alltings mått och som man genom århundraden använt för ifrågasatta vad Rosengren kallar "den vetenskapliga, epistemiska abolutismen." (ibid s 15). Det bygger också på Pierre Bourdieus användning av doxa-begreppet som "den socialt bestämda, inte alltid medvetna och ofta icke-diskursiva kunskap han (Bourdieu) försökte beskriva." (s 75)

14 I Pierre Bourdieus tankevärld, såsom den framställs t.ex. i The Forms of Capital (1983) är kulturellt kapital en typ av symboliskt kapital, nog så värdefullt i maktspelet om våra liv. 
bildningstanken i uppbyggnaden av det preussiska utbildningssystemet. Hos Herder och Hegel och Humboldt är innebörden i bildning dock att bilda sig själv, i betydelsen skapa eller formera sig själv, att uppnå sin fulla potential. Bildning blir inte i denna betydelse ett tillstånd eller ett attribut utan en ständigt pågående, livslång process. Det blir också därmed omöjligt att i förväg tala om vilket eller vilka mål bildningen har. Det är inte ovanligt att utnämna just detta drag till själva definitionen av vad som kallas den klassiska bildningstanken: "att bilda sig är att forma sig till något inte på förhand givet". ${ }^{15}$ I ett system för högre utbildning som numera är styrt av mål på alla ledder - regeringsmål, verksamhetsmål, utbildningsmål, lärandemål - mål som alltmer exakt i förväg måste tala om vad som ska uppnås, blir frågan om hur det ska gå till att forma sig till något inte på förhand givet både obekväm och besvärlig. Men jag tror att det bara är nyttigt om det upplevs som besvärligt. Målstyrningen har blivit en så självklar del av både utbildningsväsendet och den offentliga förvaltningen som helhet de senaste decennierna att det är hög tid att ställa de besvärliga frågorna. Jag ställer åtminstone några sådana frågor under mina senare principer.

En av de svenska forskare som ägnat mycket tid och tanke åt bildningen som begrepp och fenomen är Bernt Gustavsson. Han visar att synen på bildningen som en "fri, oändlig process", i likhet med definitionen jag citerade nyss, utan givna mål, är den som dominerar under vad han kallar romantiska epoker. Under sådana finner man Herder och det sena 1700-talets romantiska syn på individen; där finns Humboldt med sina skolideal och där finns hans Berlinuniversitet. Men där finns också den tidiga arbetarrörelsen kring sekelskiftet 1900 och självbildningen som ideal i folkbildningen, såsom den tog sig uttryck i studiecirkeln, folkhögskolan och studieförbundet. I andra tider, när bildningstanken blir institutionaliserad, menar Gustavsson, domineras den av förebilder och mål. Dessa förebilder och mål finns företrädesvis i den sanktionerade nationella historien, i den antika litteraturen och världslitteraturens klassiker. Just sådana områden som den som är bildad förväntas excellera i. I den första betydelsen kan man aldrig bli (färdig-)bildad, i den andra är det just det man ska bli. ${ }^{16}$

Det är också denna andra syn på bildningen som ligger bakom det ursprungligen engelska men numera främst amerikanska bildningsbegreppet liberal education. Den vill motverka en alltför snäv och tidig specialisering och ge blivande naturvetare, jurister, läkare med flera, tillgång till en bred uppsättning texter och tankar som kan bidra till att utveckla dem som professionella, som utövare av en profession. En "profession" har nämligen under inflytande av engelskan kommit att betyda ett högstatusyrke med lång utbildning och höga krav på gott omdöme. Liberal education blir också därmed gärna beroende av

15 Broady 2012, s 285 .

${ }^{16}$ Gustavsson 2012 s 311 ff. Bernt Gustavssons avhandling om bildningstanken i den tidiga svenska arbetarrörelsen och folkbildningen (Gustavsson 1991) ger en mera ingående bakgrund till bildningsbegreppet och dess historia. 
en kanon, en på förhand given lista av lämpliga klassiker som man kan reflektera och samtala kring för att tillsammans med lärare och studiekamrater öva upp sitt omdöme. Utrymmet för sådana inslag har minskat i amerikanska universitet under senare decennier och liberal education praktiseras numera framförallt av förmögna colleges, företrädesvis på USA:s ostkust. Det var också därifrån och i den tappningen som bildningstanken återkom till svensk högre utbildning under 1990-talet. Själv kom jag främst i kontakt med just den amerikanska varianten genom ett antal konferenser och utbytesprogram anordnade av ett informellt men väletablerat och elitistiskt lobby-nätverk som i dessa colleges såg en lämplig förebild för de nya högskolorna i Sverige; de kunde ägna sig åt excellent undervisning och på så sätt överlåta forskningen och de forskarbegåvningar man odlade fram till de etablerade universiteten. ${ }^{17}$

För några år sedan fanns dock också en rännil av officiella småskrifter som på olika sätt betonade värdet av bildning i högre utbildning och strävade att föra fram en seriös debatt om vad bildning kan innebära. ${ }^{18}$ Det skulle nästan kunna uppfattas som ett dåligt samvete för den strikt nyttoinriktade yrkesorienteringen som vuxit sig stark i Sverige under en lång period, kanske mer än femtio år, då den ekonomiska nyttan av högre utbildning allt tydligare setts som det egentliga och odiskutabla målet i en strid ström av politiska viljeyttringar och reformer. Den officiella rännilen torkade upp när Högskoleverkets uppgift att främja högre utbildning övergick i Universitetskanslersämbetets uppgift att bedöma den, ofta på grunder som lade långt större vikt vid ämnets kärna än vid studentens bildning.

Dessa två grunddrag i bildningen: självbildningen utan på förhand givet mål (bildningen som process) respektive bildning som förebild och mål (bildningen som produkt), är förstås två idealtyper som inte nödvändigtvis utesluter varandra. Bernt Gustavsson har också lanserat ett tredje bildningsideal som på olika sätt hämtar näring ur dessa båda: bildning som en resa. I den tyska filosofens Hans-Georg Gadamers spår talar han om hur "Resan ut blir en metafor för att öppna sig för nya tolkningar. Hela resan blir en metafor och en berättelse om hur vår förståelse av tillvaron går till /.../ Återkomsten är att införliva det nya med tidigare kända, att tillägna sig de erfarenheter man gjort där ute. Det tidigare kändas horisont har smält samman med det okändas horisont, vi har förstått annorlunda, på ett nytt sätt." ${ }^{\prime 19}$ Beskrivningen påminner inte så

${ }^{17}$ Jag tvivlar inte på att de många svenska högskolelärare som vistats en tid vid en Liberal Arts College i USA, tack vara STINT:s "Excellence in teaching"- initiativ (1999-2013) på många olika sätt haft glädje av erfarenheten. Men företrädare för STINT (The Swedish Foundation for International Cooperation in Research and Higher Education) och deras nätverk gjorde det mycket klart under ett antal möten som jag bevistade att även detta var ett huvudsyfte. STINT bildades 1994 av en miljard kronor från de nedlagda löntagarfonderna.

${ }^{18}$ Den rännil av småskrifter jag tänker på består bl.a. av Högskoleverkets rapportserie under 00-talet inom Verkets bildningsprojekt, som sammanfattas i rapporten Att fänga bildning (Högskoleverket 2009: 24).

19 Gustavsson 2012, s 317f. 
lite om hur man brukar beskriva en lärprocess, i djupare mening. Bildning i denna tappning omfattar dock mer än så; den omfattar också förmågan att använda den generella kunskapen man hämtat hem från sina bildliga - eller faktiska - resor i enskilda situationer, att tillämpa det universella på det partikulära, för att använda Gadamers termer. Och när man lär sig att göra det rätta, är det omdömet man uppövar.

Men bildning avser inte bara individens tillväxt; den innefattar också en växande insikt i samhällets funktioner och hur dessa påverkas av individens ställningstaganden. Bildning är alltså processen då man bildar de självständiga förmågorna att bedöma vad som är rätt och vad som är fel, både intellektuellt och etiskt, för såväl individen som för grupper och hela samhällen. Och då är det inte bara vad man själv lärt sig på livets resa som är av vikt utan också i högsta grad de idéer och föreställningar som finns i det samhälle man lever och verkar i. Etikern Simon Blackburn använder sig av begreppet "etiskt klimat" eller "etisk miljö" för att beskriva en del av det som ofta utan någon större precision kallas för tidsandan. Han menar att det verkligen var tänkande människor som i Tyskland på trettiotalet bidrog till nazismens uppgång. Men att deras tänkande förgiftades av ett allomslutande idéklimat som de knappast var medvetna om - en tendens att acceptera tankesätt och känslor som vi ofta inte kan se eller artikulera. Och det är sådana idéklimat som styr världen, påpekar Blackburn. ${ }^{20}$ Det bör rimligen vara en av högskolans viktigaste uppgifter att skapa förutsättningar för en bildningsgång för studenten där hon kan skaffa sig förmågan att se och avslöja sådana idéklimat hos sig själv och hos andra.

Skulle då högre utbildning vara ett motgift mot fascism? Var inte många av nazismens värsta tyranner högt utbildade män förresten? Svaret på den första frågan är kanske och på den andra, jovisst. Men jag tänker lämna de båda frågorna hängande i luften så länge. De kommer att skymta längre fram i samband med en diskussion av begreppet handlingsförmåga.

Innan jag lämnar frågan om vad bildning kan vara och vad den kan vara bra för, behöver jag dock nämna ett annat resonemang, som möjligen kan verka utmanande för en del: bildningsprocessen leder inte bara till ett liv med mening, den är en del av livets mening. Det här är ett centralt resonemang för en av 1900-talets allra största och mest inflytelserika utbildningsfilosofer, amerikanen John Dewey. Dewey kritiserade den uppdelning som finns i utbildningens värld - ja, inte bara där - mellan mål och medel. Både arbetet och utbildningen ser vi som medel för att uppnå våra mål: utbildningen för att få ett arbete och arbete för att få ett gott liv efter arbetet, i form av materiella tillgångar, fritidsaktiviteter, friheten att göra som vi vill och så vidare. Med detta synsätt,

20 "In short, Hitler could only come to power because people did think - but their thinking was poisoned by an enveloping climate of ideas, many of which may not even have been conscious. For we may not be aware of our ideas. An idea in this sense is a tendency to accept routes of thought and feeling that we may not recognize in ourselves, or even be able to articulate. Yet such dispositions rule the social and political world" (Blackburn 2001, s 3). 
menade Dewey, förminskar vi både vad som ofta är en lång och ansträngande utbildningsgång och ett ännu längre och ännu mera ansträngande arbetsliv. Arbetet och utbildningen har ett värde i sig, inte som ett sätt att upprätthålla livet eller nå fram till det liv man vill leva, utan som livet självt och i sig. Dewey sätter ofta likhetstecken mellan bildning och växande: "Eftersom att växa är det karaktäristiska för livet, är utbildning det samma som att växa - den har inget mål bortom sig själv. Skolundervisningens värde kan avläsas av i vilken grad den skapar en längtan efter kontinuerligt växande och erbjuder verktyg så att denna längtan kan tillfredsställas." ${ }^{21}$

En av Deweys starkaste och mest inflytelserika anhängare som filosof under den senare delen av 1900-talet har varit Richard Rorty. Båda har försvarat en relativt enkel och för mig tilltalande inställning till verklighet och sanning som de kallar, praktiskt nog, för pragmatism. Det är ointressant, menar Rorty, hur vårt tänkande förhåller sig någon eventuell verklighet utanför. Vi behöver inte René Descartes grund för all säkert vetande, cogito ergo sum (jag tänker därför måste jag finnas), som på 1600-talet utgjorde både baslinjen och startskottet för hela den självsäkra naturvetenskapliga revolutionen. Det som är intressant, menar pragmatisterna, är den pragmatiska frågan om huruvida vår kunskap bidrar till att utföra våra praktiska uppgifter och i förlängningen skapa ett mera demokratiskt och rättvist samhälle. På så sätt skulle för första gången teorin ställas i praktikens tjänst i stället för som det brukar, tvärtom - nämligen att praktiken betraktas som en urvattnad och degraderad form av teori. Därmed skulle också de intellektuella stå till de producerandes tjänst. ${ }^{22}$ Båda dessa principer har naturligtvis en bäring på mina resonemang kring relationen mellan teori och praktik ovan och på utformningen av en akademisk yrkesutbildning som bygger på en integrering av praktisk och teoretisk kunskap, så som jag utvecklar tanken längre fram.

Den här korta utflykten till pragmatismen gjorde jag för att sätta Richard Rortys namn i ett sammanhang. Anledningen till att jag nämner Rorty är dock egentligen för att diskutera hans tankar om lägre och högre utbildning och kopplingen till vad jag skrivit om bildning. Hans resonemang är nämligen klargörande ifråga om vad det är som utmärker, eller som bör utmärka, just den högre utbildningen. I en artikel från 1989 med titeln Education as Socialization and as Individualization inleder han med att renodla hållningen till utbildning hos den amerikanska radikala vänstern jämfört med den konservativa högern. Vad högern hävdar, säger han, är att det finns vissa eviga sanningar som ska bibringas de unga. Genom dessa sanningar kommer de att uppnå frihet. För vänstern är orsakskedjan tvärtom. Om människor får den frihet, både politisk

21 Dewey 1997 (1916), s 91.

22 Det är Dewey som Rorty refererar när han i en uppsats från 1994 med den avslöjande titeln "Truth without Correspondence to Reality" skriver "This way of thinking would, for the first time, put the intellectuals at the service of the productive class rather than the leisure class. Pragmatism would, for the first time, treat theory as an aid to practice, rather than seeing practice as the degradation of theory." (Rorty 1999, s 30) 
och ekonomisk, som de idag saknar, kommer sanningen att uppstå av sig själv genom att bojorna lossas. Därför bör utbildning, menar de på vänsterkanten, inriktas på att avslöja de härskandes konventionella sanningar, som egentligen bara är sätt att rättfärdiga förtrycket och orättvisan, och skapa frihetstörstande, självständiga individer. Men, säger Rorty, både vänster och höger ser hela utbildningskedjan från femåringen i förskolan till 22-åringen i högskolan som en enda oavbruten helhet. Detta är fel, menar han. Det finns i stället två väl åtskilda processer: dels socialisation i den lägre utbildningen, dels individualisering i den högre utbildningen. I den förra socialiseras ett djur till en människa medan i den senare revolterar individen mot samma process, genom vad Rorty kallar "självindividualisering" och "självskapande". ${ }^{23}$ Det sistnämnda stämmer till stor del överens med det svenska begreppet bildning, så som jag förstår det. Det bör aldrig vara den lägre utbildningens uppgift att ifrågasätta rådande konsensus om vad som är sant, skriver Rorty, och sätter sig därmed i onåd hos en generation utbildare i ungdomsskolan, kanske mera i Sverige än i USA, som sett just detta som sin uppgift. Individualisering måste nödvändigtvis föregås av socialisation, menar han. Detta är således också ett inlägg i debatten om pluggskolan förstås. Unga människor behöver veta och kunna vad äldre generationer har hållit för sant och funnit viktigt, genom att kunna kungar och presidenter, årtal och klassiska romaner, innan de gör uppror och finner en egen väg och en egen sanning. Det är att ge förutsättningar för det upproret som är just den högre utbildningens utmärkande drag. I och för sig skriver Rorty först att det är uppgiften bara för "non-vocational higher education" men mot slutet tycks han ångra sig och säger, klokt nog, att det är "högskolornas uppgift att erbjuda en blandning av specialiserad yrkesutbildning och stimulans till bildning". ${ }^{24}$

Inte minst från ett svenskt perspektiv ser man svagheter i Rortys resonemang. Det är orimligt att tänka sig att hela ungdomsskolan ägnar sig enbart àt oreflekterad "socialisation" i form av tradering av traditionella kunskaper, utan att odla en kritiskt ifrågasättande självständighet i tänkandet även hos riktigt unga människor. Vad som kanske är en utmaning för en del moderna pedagoger i ungdomsskolan är att acceptera att inhämtandet av en stor mängd traderade sanningar är en nödvändig huvuduppgift, som inte kan släppas bara för att det är omodernt eller konservativt. För elever och föräldrar kan det också vara en utmaning att acceptera och finna motivering för det hårda arbete som socialisation i Rortys mening innebär. Självklart kan inte heller den högre

23 "There is only the shaping of an animal into a human being by a process of socialization, followed (with luck) by the self-individuation and self-creation of the human-being through his or her revolt against that very process." Rorty 1999, s118. Man kan fråga sig vad Rorty menar med sin parentes. Antingen har de tur som får genomgå den högre utbildningen, eller också har de tur som verkligen får genomgå en sådan bildningsprocess. Kanske båda.

24 "That business is to offer a blend of specialized vocational training and provocation to self-creation." Rorty 1999, s 123. 
utbildningen bara ägna sig åt självskapande och revolt mot traditionen - det är en hel del kunskap och tradition som också ska inhämtas där.

Under denna första princip har jag velat bena ut vad vi menar när vi talar om kunskap. Jag har också velat visa att högskolans främsta uppgift bör vara att skapa förutsättningar för bildning, att provocera fram bildning rentav. Studenten skapar sig själv i en ständigt pågående, livslång resa. Ut i det okända, hem som en ny människa. Det är inte bara studentens bildning heller - och definitivt inte studenten som ska få sin bildning av de bildade lärarna. När det fungerar som det ska, är lärarna också ständigt stadda på resa, i forskningen, i samtal med kollegor, i samtal med studenter, i att bättre begripa sig själva och världen. Men hur ska det gå till? Vilka principer och föreställningar genomsyrar de utbildningstraditioner som idag så starkt präglar den svenska högskolan och vilka andra principer skulle möjligen bättre främja förståelse och bildning? 